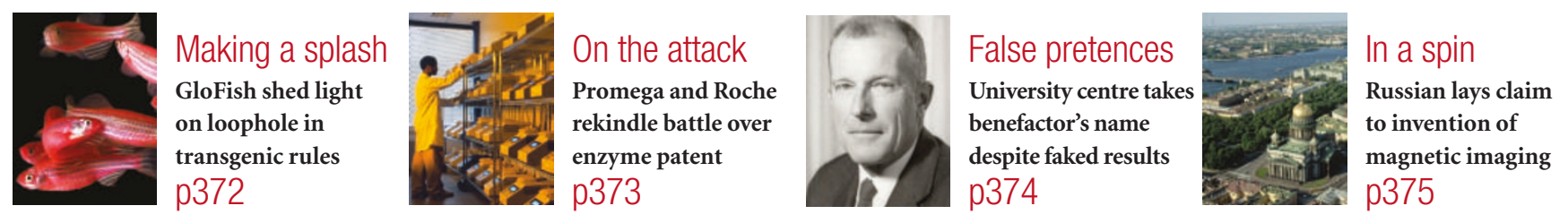

\title{
State department woos weapons researchers in bid to rebuild Iraq
}

\section{Geoff Brumfiel, Washington}

The US Department of State is launching a fast-track programme to employ former Iraqi weapons scientists in the effort to rebuild the country's shattered infrastructure.

The \$2-million initiative won government approval earlier this month, Nature has learned, and state-department officials will be travelling to Iraq within the next six weeks to begin talks with Iraqi scientists. The money will be used to start a series of pilot projects that officials hope will form the basis of larger programmes to redeploy weapons experts and civilian scientists in Iraq.

Ultimately, the state department may spend about \$20 million over the next two years to help restock laboratories and rehire Iraqi researchers who worked on nuclear, chemical and biological agents during Saddam Hussein's regime.

The pilot programme was warmly welcomed by proliferation experts, who had feared that such efforts were getting bogged down amid growing security problems in Iraq and internecine disputes inside the US government.

"I've wanted this kind of thing to happen," says David Albright, a former nuclearweapons inspector in Iraq who now heads the Institute for Science and International Security in Washington DC. Albright says that the programme has been delayed for months because the Pentagon refused to let state-department officials into Iraq after major hostilities ended on 1 May. In the intervening time, the defence department detained and interrogated many researchers in its hunt for weapons of mass destruction (see Nature 423, 371; 2003). "A lot of the scientists were being treated as criminals," Albright says.

State-department officials say that the pilot programme will approach the scientists as allies, and employ them in rebuilding the country. Although many specifics have yet to be worked out, an official at the department says that scientists will work on projects of immediate need such as water desalination, agriculture and rebuilding Iraq's health system.

Two significant challenges will be to

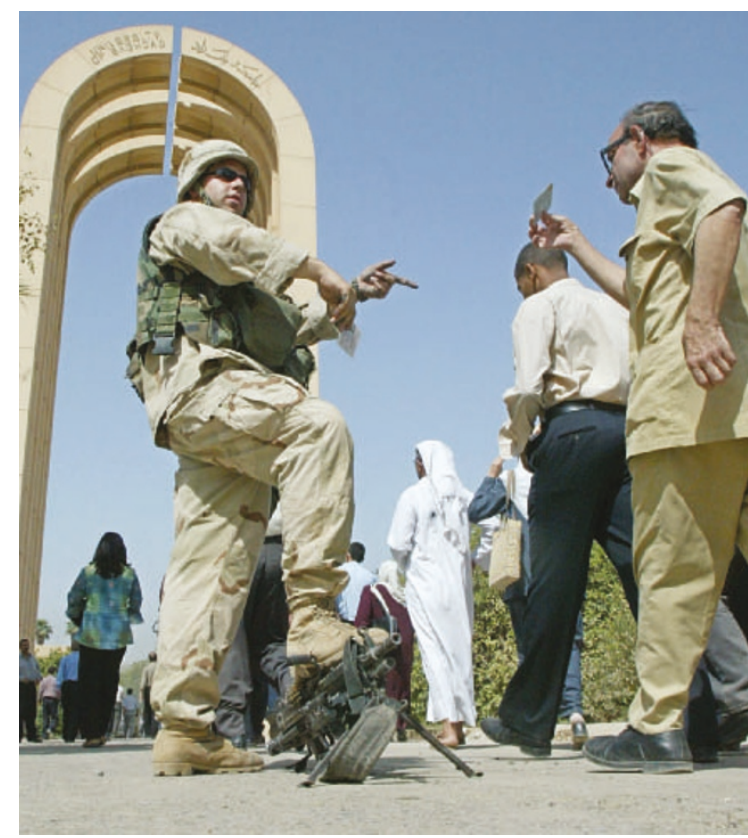

Under the gun: Iraqi academics head into Baghdad University, but the US government is increasingly keen to harness their skills.

identify scientists and engineers who were involved in Iraqi weapons programmes, and to win their cooperation. Unlike in the former Soviet Union, where many weapons researchers were sequestered in secret cities, Iraqi weapons scientists were employed at different times in diffuse locations. Many of them left the government after the 1991 Gulf War to work in industry. The state department is working with the recently established Iraqi Ministry of Science and Technology to identify and approach researchers with relevant knowledge.

Those who have travelled to Iraq in recent months say that scientists there are desperately in need of help. One state-department official visited the science deans from a dozen Iraqi universities in October. After the sanctions that followed the first Gulf War, many scientists lost contact with the broader international community, and the younger generation of researchers has been poorly trained, the official says: "They're going to need a lot of retraining and continuing education."

George Atkinson, the science adviser to secretary of state Colin Powell, is meanwhile preparing a separate proposal aimed primarily at civilian scientists. Known as the Science, Technology and Engineering Mentorship Initiative for Iraq (STEM II), this plan would provide almost $\$ 16$ million to put about 3,000 scientists in the country back to work. In addition, US mentors would be enlisted to bring the Iraqis up to speed with trends in their respective disciplines.

Unlike the current programme, which deals only with former weapons scientists, STEM II will reach out to the entire scientific community of Iraq. "STEM II is about giving a productive scientific future to people not directly involved in weapons of mass destruction," says a state-department official who helped to draft the proposal.

Experts agree that in order for both programmes to be effective, they will need to overcome several obstacles, the foremost of which is security. The continued attacks against the US-led coalition and Iraqis who support it have created a climate of fear, according to Michael Roston, a senior analyst at the Russian American Nuclear Security Advisory Council in Washington DC. "I think it will be a real uphill battle to make Iraqi scientists confident," he says.

The security situation will also make it dangerous for US researchers and statedepartment officials trying to meet with their Iraqi counterparts, adds Carol Kessler, director of the Center for Global Security at the Pacific Northwest National Laboratory in Richland, Washington.

But even if they prove difficult to implement, programmes such as these are long overdue, says Albright. In the months since major fighting ended in Iraq, many scientists have gone into hiding or fled the country. "The United States has lost a lot more than just time," he says. 